\title{
Teachers' Policy in Designing English Syllabus at Grade XI
}

\author{
Adam \\ English Education Department \\ University of Riau Kepulauan \\ adamedumy@gmail.com
}

\begin{abstract}
The present study aims to analyze the Teachers' Policy in designing English teaching syllabus at grade XI of SMAN 2 Batam. In addition to analyzing the way the teachers design their syllabus, the researcher also analyzed the problems faced by the teachers in designing the English teaching syllabus. The participants of this study were 3 English teachers who were teaching class XI of SMAN 2 Batam. The data were obtained from the interview and observation. The Supporting instruments used in this research were tape recorder, and camera. The data were analyzed through, data managing, reading and memoing, describing, classifying, and interpreting. Based on the findings, the three English teachers had followed the steps of syllabus design suggested in BSNP (Badan Standar Nasional Pendidikan or The Council of National Education Standard 2006) with respect to adapting each component of the syllabus with the teaching and learning context. It can also be concluded from the findings that the three English teachers still needed to get themselves familiar with some of the kinds of evaluation necessary for assessing a learning process. On the other hand, Most of the problems faced by the teachers in designing the English teaching syllabus were first not being able to accomplish the relationship between each components of the syllabus with the first component namely the standard competency and basic competency. The second problem was the three English teachers did not have sufficient knowledge on how to sequence the order of the difficulty level of the lesson as well as finding appropriate materials that suit their students' need. The third problem they had was they were not familiar with some types of evaluation which are very helpful in assessing a learning process. And the last problem they faced was managing time allocation. A lot of the time they were not able to finish and complete a lesson within one period of a school term due to the lack of time.
\end{abstract}

Keywords: teachers' policy and English teaching syllabus

\section{INTRODUCTION}

Education is doing a basic innovation related to the school curriculum. The innovation demands the change of the way of thinking, the learning method, and the evaluation technique. Related to this problem, the National Education Department has changed the previous curriculum Competence Base Curriculum (CBC) with the new one called KTSP (Kurikulum Tingkat Satuan Pendidikan) or School Based Curriculum. Here, curriculum is a set of plans and rules about goals, contents, and learning materials as well as 
the way of using it as guidance for implementation of learning activities that is aimed at a specific goal National Education Standardized Institution BSNP (2006). SBC is an operational curriculum which is prepared and implemented in each education unit. SBC consists of the target education unit level based on education, structure and contents of curriculum in educational unit level, education calendar and syllabus. Syllabus is a learning plan on a subject matter/specific them or a group of subject matter/ specific themes that covers competency standards, basic competencies, subject matters/learning material, learning activities, indicators, assessments, time allocation, and source/materials of learning. Syllabus is a detailed explanation of competency achievement. In the end of learning the students are hoped to master a set of competence in own self (attitude, skill, knowledge, capability, personality, principles, values, interest and conviction) passing process of active learning, creative, pleasant and effective that can be used in the future.

In addition, a syllabus should refer to students' level of ability and the year of where they are in. It is designed in such a way that it matches the teaching and learning activities in order at the end of the teaching and learning process to come to a desired goal. A syllabus provides all the planning of the lesson to be carried out in a period of teaching and learning such as a semester of teaching and learning. The whole processes are all planned prior to it that the process follows the planning and meet the desired goal but it is often the problem that teachers cannot follow the extent of the syllabus that has been designed for their activities in a classroom. They cannot, at least 80 per cent of the desired goal in a syllabus, carry out all of them. This phenomenon is often referred to the teacher's policy and the reality in a classroom. The teachers' careful policy in designing a syllabus does not match the reality happens in a class when he carries out the policy in his teaching process.

Based on the researcher's interview with some of the English teachers teaching at SMA N 2 Batam in the academic year 2015/2016, most of them are having problem with fulfilling the goal of a syllabus within one semester. One of them said that he could not reach the target by the end of the semester and left some of materials considered important. But how it is happening is depending much on how a teacher designs the syllabus in a classroom. The way the syllabus is implemented determines the extent of the success is gained in a teaching and learning process. Therefore, a study of teachers' policy of a syllabus should be carried out to reveal how the syllabus is actually implemented in the field. It should reveal how the teacher's policy is implemented in the reality in a classroom. In this research paper, 
the researcher took a title" Teachers' Policy in Designing English Syllabus at SMA N 2 Batam in the Academic year 2015-2016.

\section{METHODOLOGY}

In this research the researcher described the syllabus designing in order to give an accurate description of their syllabus development. Besides giving the description of their policies, this research will also study the problems they often have in teaching English referring to the syllabus they are fulfilling, and how they solve the problems. The phenomenon being researched can be revealed in as much qualitatively clear as possible. The qualitative analysis method applied for this research will go through cruising all the possible related phenomena that are describable happening during the development of the syllabus in an English teaching classroom context from the most observable to the least one. Thereby, covering and explaining all facts of the implementation of the syllabus.

\section{RESULTS}

Findings of the research discuss data description and analysis as well as findings and discussion of the findings. The findings are expected to answer questions stated in the formulation of the problem: 1) How do the teachers design the English teaching syllabus? 2) What are the problems faced by English teachers in designing the English teaching syllabus at Grade XI of SMA N 2 Batam? In analyzing and developing the standard competency of the syllabus, teacher A depended much on her rules of thumbs derived from her own belief and perception of what she thought to be the best for her students. She said she knew a little about Standard Competency and only did the safe things.

Teacher B considered first choosing good materials for the standard competency before some other factors like the hierarchy of the concept of knowledge, the order of the lesson based on the level of difficulty, and the relation with the time to be allocated. While, teacher $\mathrm{C}$ stated three things that need to be done in designing the standard competency, they are the order of the difficulty of the materials, the relevancy of Standard Competency and Basic Competency, and the relevancy of Standard Competency and Basic Competency within subject lessons. Concerning the relationship between the standard competency and basic competency, teacher A said that she just needed to relate the genre and the subject lesson. Similar to teacher A, teacher B also related the standard competency and basic competency to 
the materials. As said in the interview: Teacher $\mathrm{C}$ explained some steps needed for establishing the relationship between the standard competency and basic competency starting from categorizing the standard competency and basic competency of the same materials through mapping the systematical order of the lesson based on the difficulty level.

In formulating the indicators teacher A put more emphasis on students' characteristics and the subject lessons over the local potency. Teacher B on the other hand related the indicators to the local potency as well as the students' characteristics. He related them to the most noticeable local potency. Teacher $\mathrm{C}$ in a somewhat different way formulated the indicators through associating the standard competency and basic competency by means of teaching materials integration from the combination of a number of disciplines. Teacher $\mathrm{A}$ explained that she designed the materials that were slightly higher in their level of difficulty than students' current level of English proficiency by doing English test proficiency and need analysis first. She said that by doing this a teacher would know the level of the material being given to the students. Similarly, teacher B said that he also did the same way as teacher A. He said that he considered the slightly higher material than the students' level of English proficiency. He often used some tests and need analysis to find it and teacher $\mathrm{C}$ explained that she designed the material that was slightly higher in the level of difficulty than the students' current level of English proficiency. She said that it is very useful to do, because every student has different background knowledge and different level of English proficiency. She used test to know them. Teacher A said that, she related the materials to the students' age and she said in relating the materials to the student' age she just adjusted the materials to the student age by adjusting it with her syllabus, because the materials already had the standard for every class. While, teacher B said that she did not relate his materials to the students' age, because she said all the materials in his syllabus have been standardized from the educational office. So that she just follow the syllabus. On the other hand, teacher $\mathrm{C}$ said that she related her materials to the students' age by adjusting them with the curriculum given. She said that she just referred the materials with the syllabus and seeing the appropriate materials would be taught. Besides that she gave tests to the students to know the students level of English.

In designing the materials and relating those to the students' potency both teacher A and B tried to look at their students' need then identified what they need to include into the materials that can be associated with their students' potency. If it turned out to be too difficult for their students they made a simplification. To relate to the standard competency teacher A and B said that it would vary depending on the materials and the teaching techniques they deploy with the purpose of reaching the standard competency and basic competence. Teacher 
$\mathrm{C}$, also consider including the physical and cultural environment where the students live amid with those things. The classroom activities related to standard competency and basic competency both teacher A and teacher B did the same way in developing it. They explained that they just designed their lesson plan as good as possible and designing the scenario of teaching. Teacher $\mathrm{C}$ developed her activities by creating some interesting activities; she chose her activities that can attract the students' interest in learning process by looking up the standard competency and basic competency.

Teacher A, and B managed their time allocation for achieving the basic competency by putting a fixed measurement in their syllabus. After designing their materials they assigned each basic competency to the time limit for each meeting. In case they run out of time before they reach the entire basic competency, they would have an additional time if possible. While, teacher $\mathrm{C}$ tried to make a prediction on what can be achieved by one basic competency then decided the number of hours possible for each meeting. Regarding the portfolio for evaluation, teacher A, and B said that they did not include this kind of evaluation in their syllabus development because they were not used to using it. While teacher $\mathrm{C}$ said that she included it in her syllabus for the evaluation. She believed portfolio can help students see their progress over time referring to the compilation of their work.

A familiar term in School Based Curriculum is what is called Standard Competency and Basic Competence in which all the learning purposes or objectives are stated clearly with suitable operational words. It is, however, in School Based Curriculum, this component that is designed first before the other components. From the interview of three English teachers at SMA N 2 Batam, a considerable number of differing policies emerged within their responses. Teacher A's designs were not so much dependent on a theoretical approach. Much of what she did was referring to her personal experiences, beliefs and perceptual ideas. She developed the standard and basic competency ahead of the other components; objective specification over contents, and learning tasks. Regarding the objective specification before content and learning task, teachers should understand the type of syllabus they opt for in order to decide if they need to design them before the other components. The reason behind that is different learning approach will need a different way of stating a learning objective. Teacher B, on the other hand, gave a primary concern on the kinds of material to be taught. This way she believed that having decided the materials in advance one will be able to determine which objective to achieve and which is not. Each student has different cultural view points, different personalities, and learning styles. Therefore, before deciding which objectives to be learned and achieved by the students, teachers should carry out a need analysis and a test of 
English proficiency for determining the students' level of English and language variation they tend to have. Thenceforth, teachers will have a clear orientation of which kind of students they are going to teach and be able to design a learning objective accurately at least, to some extent, of that which is of value for their students.

Teacher $\mathrm{C}$ followed a three-step designs of the standard and basic competency of a syllabus: ordering the difficulty level of the materials, establish the relationship between the standard and basic competency, and the relationship within the subject lesson. The implication of that research connected to the syllabus design in ordering the difficulty level of the materials for the purpose of stating the competence in Standard and Basic Competency, it is imperative that lesson should be ordered in accordance with the natural route of acquisition. Teacher $\mathrm{C}$ in this regard fulfilled the theoretical requirement for difficulty order of the input for a lesson.

To relate the standard and basic competency within a subject lesson, teacher A and B stated that they just need to select a related genre to be taught. However, they admitted to get lost finding their way round within the zone of Standard and Basic Competency. In contrast to teacher $\mathrm{A}$, and $\mathrm{B}$, teacher $\mathrm{C}$ accomplished the relationship between the standard competency and basic competency within a subject lesson by categorizing them into the same materials then mapping the systematical order of the lesson based on the difficulty level. According to BSNP (2006) the achievement indicators should be formulated through considering the students' characteristics, subject lesson, the educational levels, local potency, using operational words which are observable and are used as a tool for instruments of evaluation. From the interview of the three English teachers, some laxity was revealed. Teachers A stated that in formulating the indicators she only focused on the students' characteristics, and the lesson to be taught, while not recognizing the other important factors as suggested by BSNP. Similarly, teacher B formulated the indicators only based on the local potency and the students' characteristics. While teacher C on the other hand only focused on the integration of materials. This is indicative that they did not follow an appropriate step in formulating the indicators in terms of the factors to be considered.

In addition to the above factors, BSNP also suggests that indicators should have the appropriate operational words with the order lower order thinking skills to higher order thinking skills. This is supported by Ishihara and Cohen (2010) who suggest that operational words should be ordered with Bloom's Taxonomy's order of thinking matching the students with the right adjustment of cognitive development stage. It is obvious from the interview that the three English teachers did not take into account of this aspect. Material is one of the 
most important elements of a syllabus. In order to carry out a syllabus, a teacher must have some fundamental knowledge about it. In developing the English teaching syllabus regarding materials teacher $\mathrm{A}, \mathrm{B}$ and $\mathrm{C}$ must have the criteria of instructional materials; first, the materials should be slightly higher in their level of difficulty than the students' current level of English proficiency. Teacher A, B, and C did relate the materials with the student's current level of English proficiency although here and there, there were still some problems and obstacles for them to optimize their development. This criterion has been suggested by some educators and experts in language teaching as one among the first things teachers should do with the materials. Regarding the usefulness of the materials for the students the three English teachers tried to relate them to the students' need concerning their daily life, experiences, and interests. Kunandar (2007) suggests that materials should have significance for students. It can be concluded that the teachers had fulfilled one of the most necessary factors of materials. Considering the depth and breadth of the materials, teacher A believed it to be related to the level of difficulty, teachers B said it to be the quality level while teacher C said it to be the tools for reaching the standard competency. Kunandar (2007) says that the depth and breadth of information contained in the materials become the aspect of the materials which are suitable with the students' level, intellectual and condition.

Concerning the size of the materials with the time allocation the three teachers stated that they needed to adjust it by considering the effectiveness of teaching- learning process every week. Besides teachers should manage and handle it well to fit the size of the materials to the time allocation. It is in accordance with Kunandar (2007) materials that teachers developed must be given the time allocation and appropriate for each activities. For the media that relate to the standard and basic competency teacher A and B said that it depends on the materials and the teaching technique they use. Teacher $\mathrm{C}$ also considered various media such as print media, students and teachers' handbooks, physical and cultural environment and technology.

In designing the classroom activity the teachers are required to have various techniques. Cooperative learning, as for instance is one of the good example that teachers can choose their activities. It has been studied that the interaction of the students within a group work such as cooperative learning can increase their mastery of critical concept. Teachers besides just assigning the students the activities should also shed some light on why they do a particular activity. Accordingly, the students will get themselves into what they are assigned for accompanied by the basic understanding of the activity. Regarding the time allocation, the three English teachers said that they tried to allocate the time for each competency. 
Teacher A and B first looked at the materials and see how many points of the competency to be achieved then assigned the appropriate hours each. Teacher $\mathrm{C}$ tended to look at the number of competencies that are possible to reach within one semester then allocate the time for it. Evaluation is the last component of a syllabus as suggested in BSNP. It is said that in a syllabus designing it is the most essential component for program reflection. Some criteria suggested in BSNP are evaluation should relate to the indicators, evaluation should evaluate students' performance, evaluation should be better using portfolio, and evaluation should also include self-assessment. Evaluation is also better with a portfolio. Teacher A and B however did not include portfolio in their evaluation due to the lack of experiences in using it. They said they are not used to using portfolio that they decided not to include it in their evaluation. While teacher C said that she did include portfolio in her evaluation to see her students' progress over time. Besides portfolio, self-assessment is also suggested in BSNP for a good evaluation. However in the interview teacher B said that he did not include self-assessment in his evaluation because he considered all other kinds of evaluation he had were already enough. This is probably because self-assessment is still a rare technique of assessment used by a large majority of teachers. Teacher $\mathrm{A}$ and $\mathrm{C}$ on the other hand believed that selfassessment is very necessary for a successful and thorough evaluation as that students feel successful and this feeling generates the need for further success. They are motivated to participate actively and enjoy classroom activities, for they are aware of the availability of success. They trust their own ability and consider tasks as challenges.

\section{DISCUSSION}

1. The teachers' policy in designing the English teaching syllabus at grade XI of $\mathrm{f}$ SMA Negeri 2 Batam in the academic year 2015-2016 has been revealed from the interview. Some of the teachers were following the ideal way of designing syllabus according to accepted theories, and some were not. Thereby, causing some limitation and problems in the development of English teaching syllabus.

2. There were five main problems they encountered in designing of the English teaching syllabus; they were the problems with designing the materials, the problem with classroom activity, the problem with media, the problem with time allocation, and the problem with the textbook/sources. 


\section{REFERENCES}

Badan Standar Nasional Pendidikan. (2006). Panduan penyusunan kurikulum tingkat satuan pendidikan jenjang pendidikan dasar dan menengah. Jakarta: BSNP.

Ishihara, Noriko \& Andrew. D. (2010). Teaching and learning pragmatics. UK: British Library.

Kunandar. (2007). Guru profesional: Implementasi kurikulum tingkat satuan pendidikan (KTSP) dan sukses dalam sertifikasi guru. Jakarta: PT. Raja Grafindo Persada. 